\title{
PENDEKATAN DAKWAH DALAM MEMBINA \\ PENGAMALAN AGAMA INA-INA
}

(Studi Kasus Ina-ina Pedagang Kaki Lima di Pasar Inpres Kota Palu)

\section{Nurwahidah Alimuddin}

Institut Agama Islam Negeri Palu

Email: irsad_irfan@yahoo.co.id

\section{Abstract:}

This paper deals with the religious practice of "ina-ina" female peddlers in Inpres Market Palu, and the analysis of pattern of da'wah (islamic preaching) which is relevant to them in order that they have comprehensive religious knowledge and implement it in their daily life. Islam is a religion that has values which lead humang beings into a happiness in this world and the hereafter. However, if Islam is not disseminated, Islam will not give good impact on its adherents. It is why preaching becomes significant. Da'wah is intended to cultivate spiritual and mental of Muslims. If Muslims are spiritually and mentally good, they become part of agent who bring peace in this world.

$$
\begin{aligned}
& \text { تناول هذا البحث الممارسة الدينية لدى الباعة المتجلات في سوق إنبريس (Pasar Inpres) ببالو، }
\end{aligned}
$$

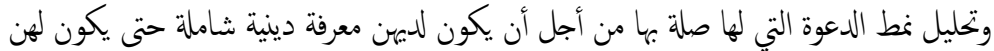

$$
\begin{aligned}
& \text { قدرة في تنفيذها في حياتهن اليومية ـفالإسلام دين له قيم تقود البشر إلى السعادة في هذا العالم المان }
\end{aligned}
$$

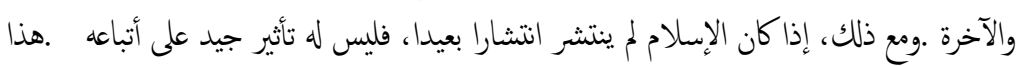

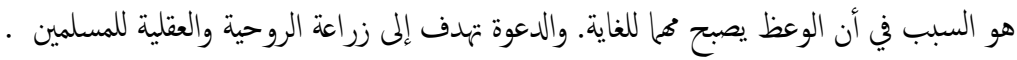

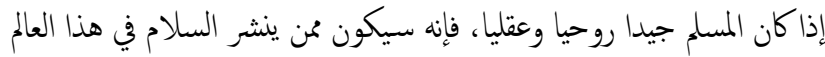

Kata Kunci: pendekatan, dakwah, ina-ina, pengalaman agama 
Nurwahidah Alimuddin, Pendekatan Dakwah.....

\section{A. Pendahuluan}

Idealnya, orang yang beragama Islam harus membuktikan eksistensi dirinya sebagai makhluk yang diciptakan oleh Allah, yaitu beribadah kepadaNya. Manusia ideal merupakan gambaran dari bentuk esensial manusia yang paling fundamental, yang tiap-tiap manusia punya pandangan ideal dalam mempersepsikan sosok manusia yang sempurna. Manusia yang dimaksudkan adalah sosok individualitas, di mana manusia dipandang sebagai sosok yang punya tanggung jawab untuk memikul bebannya sendiri dan berhak atas kerjanya sendiri dan tidak berhak memikul beban orang lain. Oleh karena itu, manusia punya tanggung jawab atas pilihan hidupnya ketika di dunia ini.

Titik tekan dalam manusia ideal adalah pada sisi kepribadian seseorang yang lebih mengutamakan kualitas dirinya untuk mencapai kesempurnaan dan keseimbangan dalam perjalanan hidupnya. Pribadi yang seimbang dan terminal akhirnya tidak berat sebelah. Kepribadian yang islami merupakan hasil akhir dari sebuah susunan kodrat manusia sebagai makhluk individual dan sosial. Sebab pada hakikatnya manusia memiliki sifat fitrah yang harus dikembangkan ke arah pencapaian kesempurnaan pribadinya. Kesempurnaan kepribadian manusia dapat terlihat pada aktualisasi dirinya sebagai manusia yang sadar akan penciptaannya, yaitu melakukan peribadatan kepada Allah SWT. ${ }^{1}$

Salah satu cara yang dilakukan untuk mengarahkan manusia bahkan mengembalikan kepada fitrahnya adalah dengan melakukan

${ }^{1}$ Damardjati Supadjar, Nawangsari, (Yogyakarta : Media Widya Mandala, 1993),

h. 9 
dakwah kepada mereka. Apalagi agama Islam adalah agama dakwah ${ }^{2}$ yang cakupannya meliputi seluruh aktifitas kehidupan umat manusia. Artinya, apapun aktivitas manusia, maka dakwah bisa masuk ke dalamnya.

Dakwah, mengajak umat manusia yang belum dan terutama telah memeluk agama Islam untuk selalu meningkatakan taqwanya kepada Allah. Dalam tujuan ini secara prakteknya adalah menganjurkan dan menunjukkan perintah-perintah Allah yang secara garis besarnya adalah Islam dan Iman, menunjukkan larangan-larangan Allah, menunjukkan keuntungan bagi orang yang mengikuti jalan Allah. menunjukkan ancaman terhadap orang yang tidak mau taat kepada Allah.

Selain itu, secara khusus dakwah juga dimaksudkan untuk membina mental umat Islam terutama yang sudah lama memeluk agama Islam namun belum melaksanakan ajaran Islam sesuai dengan ketentuan yang telah ditetapkan oleh agama Islam. Jadi, dakwah secara khusus adalah mengupayakan agar pesan-pesan dakwah sampai kepada mad,u dan diamalkan dalam kehidupannya. Dalam konteks ini, dakwah merupakan proses saling mengajak kepada yang ma'ruf dan menghindari kemungkaran. Dengan begitu, tercapailah kualitas hidup umat yang selaras dengan anjuran Allah dan Rasul-Nya. Sebuah kemaslahatan hidup, kualitas nasib umat, tidak hanya di dunia, namun lebih penting di akhirat.

${ }^{2}$ Agama Islam adalah Agama Dakwah (Missionary religion), artinya, agama yang menugaskan umatnya untuk menyebarkan dan menyiarkan Islam kepada seluruh umat manusia. Lihat Abdul Rasyid Saleh Manajemen Dakwah Islam (Cet.III ; Jakarta : Bulan Bintang, 1993) h. 1 
Nurwahidah Alimuddin, Pendekatan Dakwah.....

Namun demikian, realitas mad'u mengalami pergeseran nilai yang disebabkan oleh adanya perkembangan sosial, budaya, politik ekonomi, teknologi serta perkembangan pertumbuhan penduduk yang cepat, secara langsung maupun tidak mempengaruhi tatanan kehidupan dan budaya suatu bangsa. Banyak orang yang terhempas akibat ekonomi yang mengakibatkan ketidakberdayaan, sehingga mereka menghabiskan waktunya hanya untuk mencari kehidupan duniawiyah ; tidak lain hanya untuk sekedar memenuhi kebutuhan sehari-hari. Kondisi seperti inilah yang terjadi pada beberapa "ina-ina" pedagang kaki lima di pasar inpres Kota Palu. Mereka hanyut dengan barang-barang dagangannya mulai dari pagi hingga petang. Mereka dalam pengamatan peneliti tidak mengamalkan ajaran-ajaran Islam utamanya pelaksanaan shalat lima waktu yang sangat jelas perintah wajibnya ; padahal mereka memeluk agama Islam. Fenomena ina-ina pedagang kaki lima inilah membuat peneliti tertarik untuk menelaah dan mengkaji lebih jauh pengamalan agama mereka dan pola pendekatan dakwah yang sesuai untuk mereka agar mereka memiliki pemahaman agama yang komprehensip dan terutama agar mereka dapat mengamalkan ajaran-ajaran agama Islam dalam kehidupan sehari-harinya sesuai dengan yang telah ditetapkan oleh Allah SWT. Dalam penelitian ini kehidupan beragama ina-ina pedagang kaki lima penulis akan membatasinya pada aspek pengamalan kehidupan agama ditinjau dari dimensi ritualistik, dimensi ekperiensial dan dimensi intelektual, yaitu pengamalan sholat, pengalaman puasa dan pengamalan mengaji Alquran.

Untuk lebih terarahnya pembahasan dalam penelitian ini, maka penulis memberikan batasan masalah sebagai berikut : 
1. Bagaimana gambaran pengamalan agama ina-ina pedagang kaki lima di Pasar Inpres Kota Palu

2. Bagaimana pendekatan dakwah dalam membina pengamalan beragama ina-ina pedagang kaki lima di Pasar Inpres Kota Palu

\section{B. Kajian Teori dan Pustaka}

Pendekatan dakwah terdiri atas dua kata, yaitu kata pendekatan dan dakwah. Kata pendekatan berasal dari kata dasar dekat yang berarti tidak jauh. Kata ini mendapatkan imbuhan menjadi pendekatan yang berarti proses atau cara mendekati. ${ }^{3}$ Dalam penelitian ini pendekatan dimaknai sebagai suatu proses untuk melihat dan menentukan suatu cara yang terbaik untuk menyampaikan pesan-pesan dakwah kepada mad'u agar tujuan dakwah dapat tercapai secara efektif dan efisien.

\section{Konsep Dakwah}

Kata dakwah adalah berasal dari bahasa Arab دعا - يد عو -دعوة. Kata dakwah merupakan bentuk masdar dari kata kerja دعا sebagai mudhari yang berarti seruan, ajakan, panggilan, undangan, doá dan semacamnya 4 . Dakwah adalah upaya pembebasan umat manusia secara fundamental, yaitu akumulasi iman yang dimanifestasikan dalam sistem kegiatan sosial kemasyarakatan. Dakwah dilaksanakan secara teratur untuk mempengaruhi cara merasa, berpikir, dan bertindak pada dataran kenyataan individual dan sosiokultural dalam rangka

${ }^{3}$ Pusat Bahasa Departemen Pendidikan Nasional, Kamus Pelajar Sekolah Lanjutan Tingkat Pertama, Bandung : Remaja Rosda karya, 2003) h. 126

${ }^{4}$ Lihat Ibnu Faris, Muqayyis al Lugah, Jilid I, (ce.II, Bairut: Dar al Qutub Al Ilmiyah, 1999), h.409. Lihat Ibnu Manzur, Lisanul al Arab, Jilid III, (Qairo: Dar al Hadis, 2003), h. $366-380$ 
Nurwahidah Alimuddin, Pendekatan Dakwah.....

mewujudkan ajaran Islam dalam semua segi kehidupan. ${ }^{5}$ Pemikiran atau paradigma mengenai hakikat dakwah tidak lagi dipahami sebagai retorika atau tabligh semata, tetapi dipahami sebagai pembudayaan nilai-nilai Islam, dan usaha membangun dan mewujudkan sistem Islam dalam realitas kehidupan secara global.

Dari segi terminologi, term dakwah lebih dipahami sebagai usaha dan ajakan kepada jalan kebenaran, bukan jalan setan atau jalan kesesatan. Dalam persepktif terminologi ajakan dan seruan itu tidak dinamai dakwah bila tidak dimaksudkan untuk membawa manusia kejalan Allah. Berikut ini ada beberpa pandangan ulama tentang pengertian dakwah sebagai berikut:

Syekh Ali Mahfudh memberi pengertian dakwah :

حَثُّ النَّاس عَلَي الََْبْر وَالْهُدَا وَالامر بالمعروف و النهي عن المنكر ليفوز بسعادة العا جل و الاجل.

Artinya:

Mendorong manusia agar berbuat kebajikan dan petunjuk, menyeruh mereka berbuat yang makruf dan melarang mereka dari perbuatan yang mungkar, agar mereka mendapat kebahagiaan didunia dan di akhirat. ${ }^{6}$

Dakwah yang dimaksudkan oleh Ali Mahfudh adalah dalam rangkaian pemberin motivasi kepada mad' $u$ agar senantiasa berbuat yang ma'ruf dan meningggalkan yang mungkar demi mencapai kebahagiaan dunia dan keselamatan.

${ }^{5}$ Amrullah Ahmad(ed), Dakwah Islam dan Perubahan Sosial(Yogyakarta: PLP2M, 1985),h. 5

${ }^{6}$ Syekh Ali Mahfudh , Hidayatu al-Mursyidin (Mesir: Daar al-Kitab al-Arabi, 1952), h.17 


\section{Metode Dakwah}

Metode berasal dari kata "meta" yang berarti melalui dan "hudos" yang berarti jalan. Jadi metode bararti jalan yang dilalui. ${ }^{7}$ Metode berasal darai bahasa Inggris yaitu method artinya cara. ${ }^{8}$ Maksudnya adalah suatu cara yang bisa ditempuh, atau suatu cara atau prosedur yang disusun secara sistematis untuk mencapai suiaytu tujuan. Dalam bahasa Indonesia metode berarti cara kerja yang bersistem untuk memudahkan pelaksanaan sesuatu kegiatan guna mencapai tujuan yang ditentukan. ${ }^{9}$

Metode merupakan suatu disiplin yang diciptakan manusia untuk mencapai sasaran tertentu. Metode adalah suatu alat atau cara yang ditempuh mencapai sasaran yang dituju. Adapun pengertian metode menurut istilah, sebagaimana yang dikemukakan oleh Webeters World University Diktionary yaitu method" $A$ Systematic arraugument of thing or ideas; a way of doing. ${ }^{10}$ (metode adalah suatu sistem penyelesaian (pemecahan) sesuatu, atau ide-ide cara untuk mengerjakan.

Untuk mencapai dakwah yang efektif ditunjang oleh beberapa unsur pokok yang merupakan untaian mata rantai yang sama sekali

${ }^{7}$ Mohammad Zaein, Methodhologi Pengajaran Agama, (Yogyakarta : AK Group dan Indra Buana 1995) h. 180

${ }^{8} \mathrm{John}$ M. Echols dan Hassan Sadily, Kamus Inggris Indonesia on IngglishIndonesia Dictionary (Jakarta: Gramedia , 1988), h. 379

${ }^{9}$ Departemen Pendidikan dan Kebudayaan, Kamus Besar Bahasa Indonesia (Jakarta: Balai Pustaka; 1989) h. 581

${ }^{10}$ Lewis Mulford Adens. Ed. Webeter's world University Dictionary (Washintong : Publishers Company, Inc., 1965) h.611 
Nurwahidah Alimuddin, Pendekatan Dakwah.....

tidak bisa dipisahkan, yaitu idiologi, subjek, objek, materi, media, dan metode dakwah itu sendiri. Jadi, metode dakwah adalah penyesuaian cara dengan meteri sesuai dengan situasi dan kondisi obyek, cocok dengan lokasi dan sikap pelaksana dakwah unytuk mencapai tujuan dakwah.

Secara garis besarnya, metode dakwah yang terdapat dalam Alquran terdapat dalam QS. Al-Nahl (16) : 125

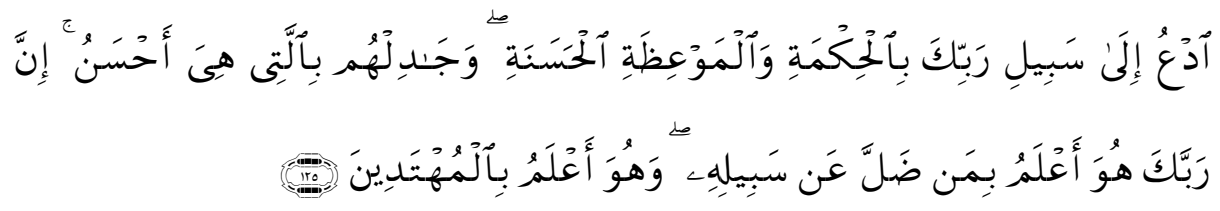

Terjemahnya :

Serulah (manusia) kepada jalan Tuhan-mu dengan hikmah dan pelajaran yang baik dan bantahlah mereka dengan cara yang baik. Sesungguhnya Tuhanmu dialah yang lebih mengetahui tentang siapa yang tersesat dari jalan-Nya dan dialah yang lebih mengetahui orang-orang yang mendapat petunjuk. ${ }^{11}$

Ayat ini, menegaskan beberapa metode yang dapat diaplikasikan, yaitu Al-Hikmah (bijaksana), Mau'izah hasanah (pelajaran yang baik), dan Al-Mujadalah (berdiskusi). Selain bersumber dari Alquran, metode dakwah dapat pula berwujud :

(a) Ceramah.

Metode suatu teknik atau metode dakwah yang menyatakan sesuatu kepada orang lain, selanjutnya bearti menyajikan keterangan kepada orang lain agar ia (mad'u) mengerti kepada yang disajikan itu.

${ }^{11}$ Departemen Agama R.I., Al-Qur'an dan Terjemahnya, (Bandung : Jumaanatul Ali Art, 2007) h. 281 
(b) Tanya Jawab.

Tanya jawab adalah penyampaian materi dakwah dengan cara mendorong sasarannya (objek dakwah) untuk menyatakan suatu masalah yang belum dimengerti dan mubaligh atau da'i sebagai penjawabnya. Dalam penggunaan metode ini harus digunakan secara bersama-sama dengan metode ceramah. Karena sifatnya membantu kekurangan-kekurangan yang terdapat dalam metode ceramah.

(c) Metode Diskusi.

Diskusi sering dimaksudkan sebagai pertukaran pikiran (gagasan pendapat) antara sejumlah orang secara lisan untuk membahas suatu masalah tertentu yang dilaksanakan dengan teratur dan bertujuan untuk memperoleh kebenaran.

(d) Propaganda.

Propaganda mengandung arti suatu upaya mensyiarkan Islam dengan cara mempengaruhi dan membujuk massa dan persuasif dan bukan bersifat otoritatif (paksaan).

(e) Keteladanan.

Metode ini dikenal dengan istilah demonstration method atau direct method yakni sesuatu diberikan dengan cara memperlihatkan sikap gerak-gerik, kelakuan, perbuatan, dengan harapan orang dapat menerima, melihat, memperlihatkan dan mencontohnya. Jadi, dakwah dengan jalan memberikan keteladanan langsung, sehingga mad'u tertarik untuk mengikuti kepada apa yang akan dicontohnya.

(f) Susupan/selipan (infiltrasi).

Metode ini berbentuk penyampaian di mana intipati agama/jiwa agama disusupkan atau diselundupkan ketika memberikan keterangan, penjelasan, pelajaran, kuliah, ceramah, pidato dan 
Nurwahidah Alimuddin, Pendekatan Dakwah.....

sebagainya. Maksudnya dengan bahan lain (umum), tidak terasa kita masukkan intisari agama kepada para hadirin.

(g) Drama (Role Playing Method).

Metode dakwah jenis ini menyajikan materi dakwah dengan mempertunjukkan dan mempertontonkan kepada mad'u agar dakwah dapat tercapai sesuai dengan yang ditargetkan.

(h) Silaturrahmi (Home Visit).

Metode ini adalah metode dakwah yang dilakukan dalam rangka menyampaikan isi dakwah kepada penerima dakwah. Termasuk di dalamnya adalah menengok orang sakit, menjenguk orang yang terkena musibah, takziyah dan lain-lain. ${ }^{12}$

Jadi, dapat dikatakan bahwa metode dakwah memiliki banyak ragam yang dapat dipergunakan oleh setiap juru dakwah secara bergantian sesuai dengan kondisi mad' $u$ yang dihadapinya.

\section{Pendekatan Dakwah}

Berdasarkan pada kajian tentang dakwah, dapat dipahami bahwa dakwah merupakan seruan, khususnya kepada umat Islam agar menjadi umat yang sempurna, yaitu manusia yang mengaktualisasikan dirinya sebagai hamba yang taat kepada Allah. Oleh karena itu, dalam rangka mencapai hal tersebut, maka diperlukan suatu cara atau pendekatan agar pesan-pesan dakwah diterima dan aktualisasikan oleh para mad'u.

Penentuan pendekatan dakwah didasarkan atas kondisi sasaran dakwah dan suasana yang melingkupinya. Dalam masyarakat yang terhimpit ekonomi, tentunya dakwah dengan pendekatan ekonomi lebih mengenai daripada pendekatan psikologis semata. Demikian juga dengan

${ }^{12}$ Dzikron Abdullah, Metodologi Dakwah (Semarang : IAIN Walisongo1989) h. 52 
pendekatan ekonomi kepada mitra dakwah yang meliputi kecemasan batin akan merupakan kesalahan jika didekati dengan ekonomi semata, sebab mereka seharusnya, didekati secara psikologis. ${ }^{13}$

Pendekatan dakwah dapat dibagi menjadi beberapa bentuk, yaitu:

\section{1) Pendekatan Sosial}

Pendekatan ini didasarkan atas pandangan bahwa penerima/mitra dakwah adalah manusia yang bernaluri sosial serta memiliki keterkaitan dan ketergantungan dengan orang lain. Interaksi sosial manusia ini meliputi semua aspek kehidupan yaiu interaksi budaya, pendidikan, politik, dan ekonomi.

2) Pendekatan Pendidikan

Pendidikan merupakan kebuuhan dan sekaligus tuntutan masyarakat, baik pendidikan formal, nonformal, maupun informal. Lembaga-lembaga pendidikan peranannya dalam pembentukan kecerdasan yang bersangkutan, kedewasaan wawasan serta pembentuka manusia moralis yang berakhlakul karimah sebagai objek maupun subjek pembangunan manusia seutuhnya.

3) Pendekatan Budaya

Setiap masyarakat memiliki budaya sebagai karya mereka sekaligus sebagai pengikat kebutuhan mereka. Para wali songo, yang memandang bangsa Indonesia dengan budaya yang tinggi secara tepat menggunakan budaya dalam dakwahnya, dan ternyata membawa hasil.

4) Pendekatan Politik

Banyak hal yang tidak dapat diselesaikan dengan pendekatan lain kecuali dengan pendekatan politik, melalui kekuasaan. Bahkan hadis Nabi

${ }^{13}$ Moh. Ali Aziz, Ilmu Dakwah, (Cet. I ; Jakarta : Kencana, 2004) h. 143 
Nurwahidah Alimuddin, Pendekatan Dakwah.....

secara khusus memerintahkan amr ma'ruf nahi munkar dengan "fal yughoyyihu biyaadihi" artinya melakukan nahi munkar tersebut dengan kekuasaan (politik) pada penguasa.

5) Pendekatan Ekonomi

Ekonomi termasuk kebutuhan asasi dalam kehidupan setiap manusia. Kesejahteraan ekonomi memang tidak menjamin suburnya kehidupan keimanan seseorang, akan tetapi sering kali kefakiran akan membawa seseorang pada kekufuran, adalah merupakan realitas yang banyak kita temukan. Pendekatan ekonomis dalam pelaksanaan dakwah pada masyarakat yang minus ekonomi untuk meningkatkan kesejahteraan hidup atau disebut dengan dakwah bil hal mutlak dilakukan sebagai pendukung stabilitas keimanan dan kontinuitas ibadah masyarakat.

6) Pendekatan Psikologis

Pendekatan ini meliputi dua aspek, yaitu pertama cara pandang dakwah terhadap manusia sebagai makhluk yang memiliki kelebihan dibanding dengan makhluk lainnya. Oleh karena itu, mereka harus dihadapi dengan pendekatan persuasif, hikmah, dan kasih sayang. Kedua, cara pandang dakwah terhadap manusia yang di samping memiliki beberapa kelebihan, ia juga memiliki berbagai macam kekurangan dan keterbatasan. Ia seringkali mengalami kegagalan mengomunikasikan dirinya di tengah-tengah masyarakat, sehingga terbelenggu dalam lingkaran problem yang mengggangu jiwanya. Oleh karena itu, dakwah harus memandang setiap mitra dakwah sebagai manusia dengan segala problematikanya. Pendekatan psikologis ini terutama bagi mereka yamg memerlukan pemecahan masalah rohani, 
baik dengan bimbingan dan penyuluhan maupun dengan metode-metode yang lain. ${ }^{14}$

\section{a) Pengamalan Agama}

Pengamalan berasal dari kata "amal" yang berarti perbuatan atau pekerjaan, mendapat imbuhan pe-an yang mempunyai arti hal atau perbuatan yang diamalkan. ${ }^{15}$ Pengamalan adalah proses (perbuatan) atau melaksanakan dan proses (perbuatan) menunaikan (kewajiban tugas). ${ }^{16}$

Agama seringkali diposisikan sebagai salah satu sistem acuan nilai (system of referenced value) dalam keseluruhan sistem tindakan (system of action) yang mengarahkhan dan menentukan sikap dan tindakan umat beragama. ${ }^{17}$ Memahami agama, tidak sebatas pada pemahaman secara formal, melainkan harus dipahami sebagai sebuah kepercayaan, sehingga melahirkan penghayatan sampai kepada pengamalan seseorang dalam kehidupan sehari-harinya. Rasa kesadaranlah yang mampu memberikan solusi dalam diri manusia dalam menjalankan kehidupannya.

Menurut Glock dan Stark ada lima macam dimensi keberagamaan yaitu keyakinan (ideologis), dimensi peribadatan atau praktek agama (ritualistik), dimensi penghayatan (eksperiensial), dimensi pengetahuan agama (intelektual). ${ }^{18}$

${ }^{14}$ Ibid., h. 147

${ }^{15}$ WJS. Poerwadaminta, Kamus Besar Bahasa Indonesia, (Jakarta : Balai Pustaka, 1985) h 33

${ }^{16}$ Depdikbud, Kamus Besar Bahasa Indonesia, (Jakarta : Pustaka, 1976) h. 25.

${ }^{17}$ Zainuddin Daulay e.d, Riuh di Beranda Satu: Peta Kerukunan Umat Beragama di Indonesia, (Jakarta: Depag, 2003) h. 61

${ }^{18}$ Jamaluddin Ancok, Fuad Nashori, Psikologi Islam, (Yogyakarta : Pustaka Pelajar, 1994) h. 77 
Nurwahidah Alimuddin, Pendekatan Dakwah.....

Pengamalan diartikan juga ibadah (ritus), ibadah (ritus) adalah bagian dari tingkah laku : seperti memakai pakaian khusus, mengorbankan nyawa dan harta, mengucapkan ucapan-ucapan formal tertentu, bersemedi (mengheningkan cipta), berdo'a (bersembahyang), memuja, mengadakan pesta, berpuasa, menari, berteriak, mencuci dan membaca. ${ }^{19}$ Sedangkan pengertian agama sebagai agama Islam, agama adalah agama yang ajaran-ajarannya diwahyukan kepada masyarakat manusia melalui Nabi saw. sebagai Rasul. ${ }^{20}$ Jadi, pengamalan agama adalah proses (perbuatan) melaksanakan atau menunaikan kewajiban yang berupa pengamalan ajaran agama Islam yang dibawa Nabi Muhammad saw. sebagai Rasul.

\section{b) Ina-Ina Pedagang kaki lima}

Pedagang kaki lima adalah istilah untuk menyebut penjaja dagangan yang menggunakan gerobak. Istilah itu sering ditafsirkan demikian karena jumlah kaki pedagangnya ada lima. Lima kaki tersebut adalah dua kaki pedagang ditambah tiga "kaki" gerobak (yang sebenarnya adalah tiga roda atau dua roda dan satu kaki). Saat ini istilah pedagang kaki lima juga digunakan untuk pedagang di jalanan pada umumnya. Sebenarnya istilah kaki lima berasal dari masa penjajahan kolonial Belanda. Peraturan pemerintahan Belanda waktu itu menetapkan bahwa setiap jalan raya yang dibangun hendaknya menyediakan sarana untuk pejalanan kaki. Lebar ruas untuk pejalan adalah lima kaki atau sekitar satu setengah meter.

\footnotetext{
${ }^{19}$ Elizabeth K. Nottingham, Agama dan Masyarakat Penganut Sosiologi Agama, (Jakarta : PT Raja Grafindo Persada, 1994) h. 4

${ }^{20}$ Harun Nasution, Islam Ditinjau dari Berbagai Aspeknya, (Jakarta : UI Press, 1979), h. 24
} 
Selain itu, pedagang kaki lima juga diartikan sebagai penjual barang dan atau jasa yang secara perorangan berusaha dalam kegiatan ekonomi yang menggunakan daerah milik jalan atau fasilitas umum yang bersifat sementara atau tidak menetap dengan menggunakan peralatan bergerak maupun tidak bergerak. Dalam konteks penelitian ini, pedagang kaki lima yang akan diteliti adalah ina-ina yang menggelar barang dagangannya di tepi-tepi jalan dan trotoar pasar inpres Kota Palu mulai dari pagi sampai petang hari.

\section{Tinjauan Pustaka}

Dakwah telah dikaji dan diteliti oleh peneliti sebelumnya, misalnya Pembinaan Narapidana Melalui Metode Dakwah Pada Lembaga Pemasyarakatan Kelas II A Palu. Penelitian ini dilakukan pada sebuah lembaga formal dengan titik penekanannya mengarah kepada metode dakwah yang dapat dilakukan untuk membina narapidana. Di samping itu, mengungkap usaha-usaha yang dapat dilakukan untuk memberikan pembinaan kepada narapidana. ${ }^{21}$

Begitu pula dengan penelitian yang berjudul Problematika Dakwah Dalam Upaya Meningkatkan Perilaku Keagamaan Siswa Di Sekolah Menengah Atas Negeri 6 Kota Palu. Dalam penelitian ini mengungkapkan tentang Problema dakwah di SMA Negeri 6 Kota Palu secara kumulatif bertumpu pada tidak adanya kebijakan kepala sekolah secara institusional yang mengikat seluruh komponen sekolah untuk melakukan dakwah. Selain itu, tidak tersedianya anggaran untuk

\footnotetext{
${ }^{21}$ Lihat Laporan Hasil Penelitian Drs. Ibrahim Latepo, M.Sos.I. Pembinaan Narapidana Melalui Metode Dakwah Pada Lembaga Pemasyarakaatn Kelas II A Palu, Tahun 2011
} 
Nurwahidah Alimuddin, Pendekatan Dakwah.....

mendukung kegiatan dakwah selain dari peringatan hari-hari besar Islam. $^{22}$

Penelitian yang telah disebutkan sebelumnya, melakukan penelitian pada lembaga-lembaga formal. Hanya saja, hasil pengkajian penulis pada penelitian tersebut belum ada yang melakukan spesifikasi pada pendekatan dakwah yang memungkinkan untuk diberikan pada inaina, sehingga mereka memiliki kesadaran untuk mengamalkan ajaranajaran agama Islam dalam kehidupannya. Namun demikian, penelitian ini akan tetap mengacu pada penelitian sebelumnya agar hasilnya dapat semakin baik dan dapat dipertanggungjawabkan secara akademik.

\section{Metode Penelitian}

\section{Jenis penelitian}

Jenis penelitian penelitian kualitatif yang bersifat eksploratif. Penelitian kualitatif, yaitu penelitian yang menghasilkan data deskriptif berupa kata-kata tertulis atau lisan dari orang-orang dan perilaku yang dapat diamati. Penelitian ini diarahkan pada latar dan individu tersebut secara utuh. ${ }^{23}$

Penelitian ini adalah Tujuan penelitian ini adalah penelitian eksploratif. Penelitian eksploratif adalah penelitian yang bertujuan ingin

${ }^{22}$ Lihat Laporan Hasil Penelitian Suriati, S.Ag.,M.Sos.I. Problematika Dakwah Dalam Upaya Meningkatkan Perilaku Keagamaan Siswa Di Sekolah Menengah Atas Negeri 6 Kota Palu Tahun 2014

${ }^{23}$ Lexy.J. Moleong, Metode Penelitian Kualitatif, (Jakarta. PT.Remaja Rosda Karya, 2002), h.3 
menggali secara luas tentang sebab-sebab atau hal-hal yang mempengaruhi terjadinya sesuatu. ${ }^{24}$

Peneliti menggunakan penelitian kualitatif-eksploratif ini karena peneliti ingin menggali secara luas dan mendalam sebab-sebab atau halhal yang mempengaruhi terjadinya sesuatu. Dalam hal ini realitas ina-ina pedagang kaki lima yang tidak menampakkan pengamalan agama Islam, khususnya shalat lima waktu. Di samping itu, lewat penggalian yang secara mendalam ini, peneliti juga sekaligus akan mencari pendekatan dakwah yang memungkinkan untuk membina mereka agar tumbuh kesadaran untuk mengamalkan agama Islam, khususnya pelaksanaan shalat, puasa dan mengaji.

\section{Teknik pengumpulan data}

a. Observasi.

Observasi, yaitu cara untuk mengumpulkan data dengan mengamati secara langsung terhadap subjek yang diteliti, ${ }^{25}$ dalam hal ini yang diobservasi adalah ina-ina pedagang kaki lima.

Observasi yang dilakukan oleh peneliti tidak hanya dilakukan di lokasi mereka berjualan saja, akan tetapi penulis akan melakukan observasi sampai mereka pulang ke rumahnya untuk melihat pengamalan agama para ina-ina tersebut.

b. Wawancara (interview).

Teknik wawancara yang penyusun gunakan dalam penelitian ini adalah structure interview (wawancara terstruktur). Pertanyaan-

${ }^{24}$ Suharsimi Arikunto, Prosedur Peneltian Suatu Pendekatan Praktik, (Jakarta: PT Rineka Cipta, 2006), h. 7

${ }^{25}$ Dudung Abdul Rohman, Metode Penelitian Sejarah (Jakarta: logos wacana Ilmu, 1999), h. 32 
Nurwahidah Alimuddin, Pendekatan Dakwah.....

pertanyaan yang diajukan sudah dipersiapkan secara lengkap melalui interview guide (pedoman wawancara). ${ }^{26}$ Interview guide inilah yang akan dijadikan sebagai instrumen untuk memperoleh data tentang pendekatan dakwah dalam membina kesadaran pengamalan agama ina-ina pedagang kaki lima di Pasar Inpres Kota Palu.

c. Dokumentasi.

Dokumentasi, yaitu mencari data mengenai hal-hal yang berupa catatan, transkip, buku, surat kabar, majalah, prasasti, notulan rapat, agenda dan sebagainya. ${ }^{27}$ Dalam studi ini peneliti mencari dan mempelajari beberapa dokumen yang berkaitan dengan penelitian yang dilakukan seperti gerakan dakwah yang telah di teliti sebelumnya begitupula pola kehidupan ina-ina yang telah diteliti sebelumnya, dan lain-lain.

\section{Pendekatan penelitian}

Beberapa pendekatan yang dipergunakan dalam penelitian ini, antara lain:

a. Pendekatan sosiologis, yaitu pendekatan yang menelusuri gejalagejala sosial dan permasalahan yang terjadi pada sekitar kehidupan ina-ina pedagang kaki lima.

b. Pendekatan psikologis, yaitu pendekatan yang dipergunakan untuk menyelami suasana bathin terutama para ina-ina pedagang kaki lima pasar inpres Kota Palu.

c. Pendekatan agamais, yaitu pendekatan yang digunakan oleh penulis untuk melihat sikap, cara berpikir, dan berperilaku sesuai dengan

${ }^{26}$ Michael H. Walizer dan Paul L. Wienir, Metode dan Analisis Penelitian, Alih bahasa Arief Sukadi Sadiman (Jakarta: Erlangga,1990), h. 253

${ }^{27}$ Suharsimi Arikunto, Metode Research II (Yogyakarta: Andi Offset, 2000), h. 236 
patron agama Islam bagi para ina-ina pedagang kaki lima pasar inpres Kota Palu

\section{Teknik analisis data}

Penelitian ini adalah kualitatif, sehingga analisis data dilakukan dengan mengatur secara sistematis data observasi dan transkrip wawancara serta data lapangan lainnya seperti yang dikemukakan oleh Lexy J. Moleong, yaitu analisis data kualitatif merupakan proses mencari dan mengatur secara sistematis transkrip wawancara, catatan lapangan dan bahan lainnya yang telah dihimpun untuk memperoleh pengetahuan dan pengalaman mengenai data tersebut serta mengkomunikasikan apa yang telah ditemukan. ${ }^{28}$

Data yang sudah terkumpul, penulis analisis dengan cara :

a. Melakukan reduksi data, yaitu menganalisa data dengan mengawali dari masalah-masalah yang bersifat khusus kemudian menyimpulkan secara umum.

b. Melakukan display data, yaitu menganalisa data dengan mengawali dari masalah yang bersifat umum kemudian menarik kesimpulan secara khusus. ${ }^{29}$

c. Melakukan verifikasi data, yaitu menganalisa data dengan cara membandingkan pendapat atau data yang satu dengan data yang lain kemudian mengambil suatu kesimpulan. ${ }^{30}$

${ }^{28}$ Lexy J. Moleong, Metodologi Penelitian Kualitatif, (Cet. XVIII ; Remaja Rosda Karya, 2000) h. 23

${ }^{29}$ Ibid., h. 75

${ }^{30}$ Sugiyono, Metode Penelitian Kuantitatif, Kualitatif dan R\&D, (Cet. IV; Bandung: CV.Alfabeta, 2008), h. 75. Bandingkan pula dengan metode induktif oleh Sutrisno Hadi, Metodologi Reseach (Yogyakarta: Gajah Mada University Press, 1998) h. 36 
Nurwahidah Alimuddin, Pendekatan Dakwah.....

\section{Data Dan Sumber Data}

Telah dikemukakan sebelumnya bahwa penelitian ini adalah jenis penelitian kualitatif. Oleh karena itu, sesuai dengan jenis penelitian ini, maka data yang akan dielaborasi adalah data yang berbentuk pernyataan-pernyataan yang diperoleh dari lapangan.

Sumber data yang digunakan adalah sumber data primer dan sekunder. Sumber data primer yang dimaksud ialah data yang bersumber langsung dari lapangan, yaitu para ina-ina yang menjual di jalan dan trotoar pasar inpres Kota Palu. Sumber data primer ini diklasifikasi berdasarkan area tempat mereka berjualan. Inilah titik tolak penulis menentukan orang-orang yang menjadi sumber data primer dalam penelitian. Adapun sumber data sekundernya adalah sumber tak langsung, yaitu para muballigh atau muballighat yang turut andil dalam memberikan dakwah di daerah tempat tinggal para ina-ina.

\section{Hasil Penelitian}

Ina-ina pedagang kaki lima di Pasar Inpres Kota Palu adalah ratarata orang-orang yang berasal gunung Silae. Wilayah ini terbilang relatif jauh dari pasar, sehingga untuk mengais rezeki mereka harus meninggalkan kampungnya sejak subuh hari. Mereka memilih pekerjaan ini disebabkan "keterpaksaan" karena pekerjaan awalnya sebagai petani tidak menjanjikan lagi. Ina-ina yang berjualan di Pasar Inpres Kota Palu berdasarkan hasil temuan terbagi atas dua kelompok, yaitu ina-ina yang kurang mengamalkan agamanya sebagai orang Islam dan ina-ina yang memiliki kesadaran untuk mengamalkan ajaran-ajaran agama Islam. Inaina yang kurang mengamalkan agama Islam, bahkan kurang peduli dengan agama itu sendiri adalah ina-ina yang lebih mementingkan 
barang dagangannya dibandingkan agamanya sendiri. Dengan kata lain ina-ina yang lebih mementingkan hal-hal yang bersifat duniawiahnya dibandingkan dengan urusan-urusan ukhrawinya. Di sisi lain, terdapat kelompok ina-ina yang dengan tekun dan sadar mengamalkan ajaranajaran agama Islam. Mereka adalah orang-orang yang menyeimbangkan antara kepentingan duniawinya dan dengan kepentingan ukhrawinya. Kedua kelompok ina-ina tersebut memiliki kesamaan daerah asal dan kesamaan perilaku dalam berdagang serta kesamaan dalam tingkat perekonomiannya satu sama lain. Mereka juga memiliki alasan yang sama memilih pekerjaan sebagai ina-ina. Hanya saja mereka terdapat perbedaan dalam pengamalan agama. Salah satu penyebab terjadinya hal tersebut yang dapat dikemukakan adalah adanya salah satu kelompok yang tidak mendapatkan bimbingan dan pengajaran tentang agama dan konsekuensi beragama sebagai orang Islam. Kelompok ina-ina yang mengabaikan agama adalah kelompok yang tidak memiliki wadah yang dapat dijadikan sebagai tempat menimba ilmu agama, sementara kelompok ina-ina yang menyeimbangkan pengamalan agamanya memiliki wadah untuk senantiasa menambah dan memperbarui pemahaman agama mereka.

Pendekatan dakwah yang cukup efektif yang dapat diterapkan pada ina-ina adalah pendekatan kelembagaan. Pendekatan ini bisa dilakukan dengan membentuk lembaga di wilayah tersebut untuk mengorganisir kegiatan dakwahnya, dapat pula lembaga dakwah yang telah terbentuk yang berasal dari luar daerah tersebut yang proaktif memberikan dakwah di wilayah ina-ina tersebut. Pendekatan dengan membentuk lembaga, seperti majelis taklim, pengurus-pengurusnya dapat direkrut dari orang-orang yang ada di sekitarnya untuk mengurus dan 
Nurwahidah Alimuddin, Pendekatan Dakwah.....

mengembangkan majelis ini. Para penguruslah yang akan bergerak sedemikan rupa agar kesinambungan dakwah dapat terus berjalan. Namun, di sisi lain, wilayah ina-ina yang relatif tidak memiliki kemampuan untuk membentuk ; terutama mengurus lembaga dakwahnya, maka lembaga dakwah yang telah terbentuk yang berasal dari luarlah yang harus proaktif untuk memberikan dakwah. Sebab hanya dengan pendekatan seperti itu yang cukup memungkinkan dilakukan di wilayah ina-ina yang berdomisili di kaki Gunung Silae yang tingkat pengamalan agamanya masih sangat kurang. Apalagi ina-ina di kaki Gunung Silae tidak sama dengan masyarakat kota yang bisa mengakses informasi keagamaan melalui berbagai media, seperti televisi, radio, surat kabar, dan lain-lain. Kelompok ina-ina ini adalah kelompok yang harus “disuapi” agar mereka bisa mendapatkan ilmu pengetahuan agama.

\section{E. Penutup}

Setelah penulis memaparkan data hasil temuan di lapangan, maka penulis berkesimpulan bahwa :

a. Pengamalan agama ina-ina, pedagang kaki lima di pasar Inpres Kota Palu khususnya pada masalah kewajiban mendirikan shalat belumlah maksimal. Mereka melaksanakan shalat tidak secara terus menerus sesuai waktu yang telah ditentukan. Bahkan ada di antara mereka yang tidak merasa terbebani manakala mereka tidak shalat. Terjadinya hal ini disebabkan tidak adanya akses mempelajari agama di daerah tempat mereka tinggal.

b. Pendekatan dakwah yang memungkinkan efektif dilakukan adalah pendekatan kelembagaan, yaitu membentuk lembaga dakwah seperti majelis taklim agar lembaga ini dapat mengurus, menghimpun, dan 
mengembangkan gerakan dakwah di wilayah itu. Dapat pula lembaga dakwah yang telah terbentuk yang berasal dari luar daerah yang proaktif memberikan dakwah di wilayah ina-ina tersebut, sebab inaina tidak sama dengan masyarakat kota yang bisa mengakses informasi keagamaan melalui berbagai media, seperti televisi, radio, surat kabar, dan lain-lain. Kelompok ina-ina ini adalah kelompok yang harus "disuapi" agar mereka bisa mendapatkan ilmu pengetahuan agama.

\section{Implikasi Penelitian}

Implikasi dalam penelitian ini terutama tertuju kepada aktivis dan pegiat dakwah terutama yang mereka yang berbasis pada lembaga dakwah sebagai berikut :

1. Daerah gunung Silae terdapat ina-ina pedagang kaki lima yang merupakan mad'u dengan tingkat ekonomi yang sangat minim mengais rezekinya di Pasar Inpres Kota Palu, pengamalan agamanya kurang sesuai dengan tuntunan dantuntutan agama Islam, sehingga perlu mendapatkan pembinaan.

2. Pendekatan dakwah yang memungkinkan dilakukan adalah pendekatan kelembagaan sebagaimana yang dilakukan oleh al-khairat untuk memberikan pembinaan kepada ina-ina pada bahagian lain di wilayah itu.

3. Pemerintah dalam hal ini Kantor Kementrian Agama perlu memberikan perhatian kepada mad'u seperti ini karena mereka adalah umat Islam, berada pada tingkat ekonomi di bawah rata-rata, dan minim pengetahuan agamanya agar tidak terjadi hal yang kita tidak inginkan "kefakiran itu dekat dengan kekufuran". 
Nurwahidah Alimuddin, Pendekatan Dakwah.....

\section{Daftar Pustaka}

Abdullah, Dzikron Metodologi Dakwah, Semarang : IAIN Walisongo1989

Adens, Lewis Mulford Ed. Webeter's world University Dictionary, Washintong : Publishers Company, Inc., 1965

Ancok, Jamaluddin dan Fuad Nashori, Psikologi Islam, Yogyakarta : Pustaka Pelajar, 1994

Ahmad, Amrullah (ed), Dakwah Islam dan Perubahan Sosial, Yogyakarta: PLP2M, 1985

Arikunto, Suharsimi Metode Research II, Yogyakarta: Andi Offset, 2000

Arikunto, Suharsimi Prosedur Peneltian Suatu Pendekatan Praktik, Jakarta: PT Rineka Cipta, 2006

Aziz, Moh. Ali Ilmu Dakwah, Cet. I ; Jakarta : Kencana, 2004

Departemen Agama R.I., Alquran dan Terjemahnya, Bandung : Jumaanatul Ali Art, 2007

Departemen Pendidikan dan Kebudayaan, Kamus Besar Bahasa Indonesia, Jakarta: Balai Pustaka; 1989

Depdikbud, Kamus Besar Bahasa Indonesia, (Jakarta : Pustaka, 1976

Daulay, Zainuddin e.d, Riuh di Beranda Satu: Peta Kerukunan Umat Beragama di Indonesia, Jakarta: Depag, 2003

Echols, John M. dan Hassan Sadily, Kamus Inggris Indonesia on IngglishIndonesia Dictionary, Jakarta: Gramedia , 1988

Faris, Ibnu Muqayyis al Lugah, Jilid I, Cet. II, Bairut: Dar al Qutub Al Ilmiyah, 1999

Hadi, Sutrisno Metodologi Reseach, Yogyakarta : Gajah Mada University Press, 1998

Harun Nasution, Islam Ditinjau dari Berbagai Aspeknya, Jakarta : UI Press, 1979

Ibrahim Latepo, Pembinaan Narapidana Melalui Metode Dakwah Pada Lembaga Pemasyarakaatn Kelas II A Palu, Tahun 2011

Mahfudh, Syekh Ali Hidayatu al-Mursyidin, Mesir: Daar al-Kitab al-Arabi, 1952

Manzur, Ibnu Lisanul al Arab, Jilid III, Qairo: Dar al Hadis, 2003 
Moleong, Lexy J. Metodologi Penelitian Kualitatif, Cet. XVIII ; Remaja Rosda Karya, 2000

Metode Penelitian Kualitatif, Jakarta. PT.Remaja Rosda Karya, 2002

Nottingham, Elizabeth K. Agama dan Masyarakat Penganut Sosiologi Agama, Jakarta : PT Raja Grafindo Persada, 1994

Poerwadaminta, WJS. Kamus Besar Bahasa Indonesia, Jakarta : Balai Pustaka, 1985.

Pusat Bahasa Departemen Pendidikan Nasional, Kamus Pelajar Sekolah Lanjutan Tingkat Pertama, Bandung : Remaja Rosda karya, 2003

Rohman, Dudung Abdul Metode Penelitian Sejarah Jakarta: logos wacana Ilmu, 1999

Saleh, Abdul Rasyid Manajemen Dakwah Islam, Cet. III ; Jakarta : Bulan Bintang, 1993

Sugiyono, Metode Penelitian Kuantitatif, Kualitatif dan R\&D, Cet. IV; Bandung: CV. Alfabeta, 2008

Supadjar, Damardjati Nawangsari, Yogyakarta : Media Widya Mandala, 1993

Suriati, Problematika Dakwah Dalam Upaya Meningkatkan Perilaku Keagamaan Siswa Di Sekolah Menengah Atas Negeri 6 Kota Palu Tahun 2014

Walizer, Michael H. dan Paul L. Wienir, Metode dan Analisis Penelitian, Alih bahasa Arief Sukadi Sadiman, Jakarta: Erlangga, 1990

Zaein, Mohammad Methodhologi Pengajaran Agama, Yogyakarta : AK Group dan Indra Buana 1995 